\title{
Therapeutic Targets for Inhibitors of Glycosylation
}

\author{
Dominic S. Alonzi and Terry D. Butters*
}

\begin{abstract}
Small molecule inhibitors of glycoconjugate metabolism are being exploited for therapeutic benefit in a number of human disorders. As examples of this class of compound, imino sugars, as monosaccharide mimics, have a number of advantages for compound design and synthesis to define biological activity. As polyhydroxylated molecules, each chiral centre offers manipulation to generate isomers with restricted or enhanced mimicry, and the endocyclic nitrogen atom is readily modified to gain selectivity, increase potency or improve pharmacodynamics. This review focuses on the discovery of imino sugars that have considerable potential for treating a diverse range of diseases, from lysosomal storage disorders diabetes and cystic fibrosis to viral pathogenesis, and addresses the mechanism of action that is dictated by structural modification.
\end{abstract}

Keywords: Hepatitis virus · HIV · Imino sugar · Lysosomal storage

\section{Introduction}

Imino sugars are polyhydroxylated intramolecular nitrogen molecules that adopt similar spatial conformations to monosaccharides. These properties endow imino sugars with inhibitory potency for glycosidases and in some cases glycosyltransferases where structural mimicry of the acceptor is the basis for competitive inhibition. ${ }^{[1]}$ Many imino sugars are natural products but chemical synthesis involving manipulation of each stereocentre has allowed improvement, largely through empirical studies, in potency and selectivity.

The disorders that have been treated in man range from the orphan drug diseases where less than 1 in 10,000 persons may be affected, to viral pathogenesis where as many as 500 million people may have an exposure that is life threatening. One application of imino sugars that will be discussed is the treatment of disorders of catabolism leading to lysosomal accumu-

\footnotetext{
${ }^{\star}$ Correspondence: Dr. T. D. Butters

Oxford Glycobiology Institute

Department of Biochemistry

Oxford University

South Parks Road

Oxford OX1 3QU, UK

Tel.: +44 1865275725

Fax: +44 1865275216

E-mail: terry.butters@bioch.ox.ac.uk
}

lation of undegraded or partially degraded glycosphingolipids (GSL) that results in pathology. ${ }^{[2-4]}$

\section{Lysosomal Storage Disorders (LSD)}

Lysosomal degradation of glycosphingolipids is catalysed by glycosidases and a number of inherited disorders are seen in man where the lack of lysosomal enzyme activity, due to mutations in the gene encoding the relevant protein, results in lysosomal storage of the enzyme's substrate. ${ }^{[1,5]}$ More than 40 lysosomal storage diseases are known of which at least ten are due to defective sphingolipid degradation. ${ }^{[6,7]}$ The family of lysosomal storage disorders includes Gaucher, Fabry, Tay-Sachs, Sandhoff disease, GMI gangliosidosis where GSLs are the major accumulated products. However, GSLs, such as GM2 and GM3 ganglioside, may also accumulate secondarily as seen in Niemann-Pick type C (NPC) disease. This additional accumulation, predominantly observed in axons of neurons and ectopic dendrites appear identical to those observed in the gangliosidoses. ${ }^{[8]}$ Defects in ganglioside metabolism result in neuronal dysfunction due to secondary storage of GSLs in NPC. The mechanism behind the accumulation of gangliosides leading to pathogenesis in this and many types of lysosomal storage, is unclear but pro-inflammatory cytokine cascades are involved. ${ }^{[9]}$

\section{Substrate Reduction Therapy}

Pharmacological intervention as a therapy for the LSDs, as an alternative to enzyme replacement therapy (ERT) was realised following the discovery that $N$-alkylated imino sugars of gluco- and galacto- stereochemistry were potent inhibitors of ceramide glucosyltransferase (CGT). ${ }^{[10-12]}$ Alkyl and arylalkyl chains were effective and 3-18 carbon atoms were required for inhibitory activity that increased with chain length as assessed using in vitro assays and cellular studies. ${ }^{[10-13]}$ The therapeutic strategy of SRT is to reduce GSL substrate influx to the lysosome by partial biosynthetic inhibition. The residual mutant enzyme activity then has a greater kinetic opportunity to catabolise the lysosomal burden, eventually leading to clearance. A compound that had previously been in clinical trials for HIV, $N$-butyl-DNJ (1), was successful in efficacy studies in Gaucher type I patients, ${ }^{[14]}$ leading to approval of use in Europe, Israel and USA and is now marketed as Zavesca by Actelion. The evaluation of Zavesca in other indications, including the gangliosidoses and NP-C has been reported with mixed success. ${ }^{[15-25]}$ Several attempts to improve inhibitory potency, or selectivity have been published, mostly based on lipophilic substitution of the piperidine endocyclic nitrogen ${ }^{[26]}$ but conduramine ${ }^{[27]}$ and pyrrolidine scaffolds have been assessed.[10,28]

\section{Chaperone Mediated Therapy}

The discovery that imino sugars with the correct stereochemistry are potent inhibitors of glycosidases that are deficient in the LSDs, also enhance enzymatic activity at sub-inhibitory concentrations, ${ }^{[29]}$ has led to a further therapeutic opportunity to exploit these molecules. Imino sugar binding to proteins as they fold in the endoplasmic reticulum (ER) helps to stabilise enzyme conformation under non-inhibitory conditions, since there is no substrate in the ER lumen. This interaction enables enzymes to traffic to the lysosome more 
efficiently (i.e. less misfolded enzyme has been degraded) leading to an increase in enzyme activity following dissociation of the inhibitor in a substrate-rich, low $\mathrm{pH}$ environment. Studies with Fabry and Gaucher mutant cells ${ }^{[30,31]}$ and transgenic mice engineered for human mutations in $\alpha$-galactosidase and $\beta$-glucocerebrosidase ${ }^{[32,33]}$ have formed the basis for a clinical evaluation. Deoxygalactonojirimycin, DGJ (2), is an effective chaperone for $\alpha$-galactosidase and is in Phase III clinical trials (Amicus Therapeutics). In Phase II clinical trials in Gaucher patients (Amicus Therapeutics), the lack of clinical improvement, despite an enhancement of mutant glucocerebrosidase activity by isofagamine (3), was unexpected and progression to Phase III has been temporarily halted.

Zavesca also has shown some improvement in mutant N370S glucocerebrosidase and may therefore have a dual activity in the clinical improvement of disease phenotype in Gaucher disease. ${ }^{[34]}$

Glycogenolysis type II or Pompe disease, is a deficiency in lysosomal $\alpha$-glucosidase activity and is a tractable disease for CMT. The small molecular weight, lack of cytotoxicity and glucose mimicry of the deoxynojirimycins endows these molecules with properties as being good candidates for therapy and has led to Phase I clinical trials of DNJ (4) (Table 1). The alkylated DNJ compounds are also potential therapeutics for this indication and $N$-butyl-DNJ has also shown a synergistic activity with ERT in enhancing enzyme activity.[36]

\section{Type II Diabetes}

Miglitol ( $N$-hydroxyethyl-DNJ) was the first imino sugar to be granted approval for any therapeutic indication in man (5) (Table 1). As a potent $\alpha$-glucosidase inhibitor, this compound reduces the activity of the intestinal disaccharidase, especially following a meal, and is used to control glucose uptake in compromised individuals with type 2 diabetes. The choice of this compound by Bayer now seems rather fortunate since it shows few other side effects due to inhibition of ceramide glucosyltransferase and ER- $\alpha$-glucosidases in cellular assays (Alonzi \& Butters, unpublished). Zavesca, $N$-butyl-DNJ, also inhibits intestinal disaccharidases and is regarded as a side effect that can be readily resolved in patients taking this drug for the treatment of Gaucher disease. Recent data by Aerts and colleagues have described a further mechanism shared by $N$-butyl-DNJ and some adamantanyl-DNJ compounds (6) that leads to an improvement in glycemic control in diabetes induced obesity. Insulin sensitivity can be increased following GSL inhibition and like inhibition of di- saccharidases, aids the reduction in circulating glucose levels. [37,38,52]

\section{Inhibition of Viral Biogenesis}

Imino sugar glucose mimics, such as DNJ and castanospermine, were found to have potential HIV treatment, with $\alpha$-glucosidase inhibition appearing to be the mechanism that reduced the titre of HIV (human immunodeficiency virus) in vitro. ${ }^{[53,54]}$ It was subsequently shown that $N$-alkylation of DNJ with an $N$-methyl, $N$-ethyl or $N$-butyl side chain greatly increased this activity at non-cytotoxic concentrations. ${ }^{[55]}$ Further work confirmed ER $\alpha$-glucosidase inhibition to be a candidate mechanism for the antiviral activity of $N \mathrm{~B}-\mathrm{DNJ}$ following analysis of the $\mathrm{N}$-linked glycosylation of HIV envelope glycoprotein gp-120 that revealed profound alterations in the presence of this compound. ${ }^{[56]}$ Using conformationally-dependent antibodies to gp 120 , it was discovered that $\alpha$-glucosidase inhibition led to subtle changes in the V1 and V2 loops of gp120 folding, preventing the conformational change required to expose the fusogenic peptide gp41.[57,58] This resulted in the inability of HIV to fuse with the target cell thus blocking the life cycle of the virus at the viral entry stage. When $N B-D N J$ was evaluated in patients with AIDS (acquired immunodeficiency syndrome) the drug was poorly tolerated at high doses and the concentration achieved in plasma was insufficient to achieve a reduction in viral titre alone ${ }^{[59]}$ or in combination with azidothymidine (AZT). ${ }^{[60]} \mathrm{A}$ 6-butanoyl ester derivative of castanospermine (7) was 50 times more potent than NB-DNJ against HIV-1, ${ }^{[39]}$ and has demonstrated efficacy for reducing viremia in Herpes simplex virus (HSV-1), ${ }^{[40]}$ hepatitis $\mathrm{B}(\mathrm{HBV})^{[41]}$ and mouse models for dengue virus. ${ }^{[42]}$ Preliminary data for combination therapy (with interferon) Phase II clinical trials were reported in 2007 (Migenix).

The inhibition of ER glucosidases causes the disruption of the N-linked oligosaccharide processing in cells. Imino sugars cross the plasma membrane quickly and efficiently such that the concentration of compound in the cytosol is at equilibrium with the extracellular concentration. ${ }^{61]}$ $\mathrm{N}$-Alkylated DNJ analogues enter the cell rapidly where they directly interact with the ceramide glucosyltransferase on the cytosolic side of the cis Golgi. However, to interact with ER $\alpha$-glucosidases the imino sugar has to gain entry to the ER and hence alter $\mathrm{N}$-linked processing. The rate of entry into this organelle is unknown, but the concentration of imino sugar is much lower in the ER lumen, than is supplied exogenously. Evidence for this comes from experiments where the concentration re- quired to inhibit ER $\alpha$-glucosidase I has been measured, often requiring $1-10,000$ times that which inhibits the purified enzyme in vitro, ${ }^{[62]}$ in contrast to inhibition of ceramide glucosyltransferase. ${ }^{[61]}$

Since the finding that imino sugars were antiviral against HIV, there has been considerable interest in studying the antiviral effects of $\mathrm{N}$-alkylated imino sugars against hepatitis viruses belonging to the Flaviridae family, e.g. $N$-nonyl DNJ ( $N \mathrm{~N}$ DNJ) (8) against woodchuck hepatitis virus (WHV) ${ }^{[43]}$ and bovine viral diarrhoea virus (BVDV). ${ }^{[44]}$ The secretion of HBV from cultured hepatoblastoma cells has also been demonstrated to be sensitive to $\alpha$-glucosidase inhibition. Woodchucks chronically infected with WHV, the animal model of HBV, following treatment with the long chain $\alpha$-glucosidase inhibitor, NN-DNJ (8), showed a dose-dependent decrease in enveloped WHV. This antiviral effect correlated with an increase in glucosylated glycoproteins detected in plasma. ${ }^{[43]}$

Experiments performed in MDBK cells infected with BVDV, the cell culture model of hepatitis $\mathrm{C}$, have shown that $N \mathrm{~B}$ $\mathrm{DNJ}$ and to a greater extent $N \mathrm{~N}-\mathrm{DNJ}$ reduced the secretion of infectious BVDV. ${ }^{[45]}$ The association of the BVDV envelope glycoproteins E1 and E2 with calnexin is prevented in the presence of $\mathrm{NB}-\mathrm{DNJ}$ resulting in misfolding and inefficient formation of E1 and E2 heterodimers. ${ }^{[44]}$ The disrupted folding and association of E1 and E2 is dose dependent and correlates with antiviral effects of $N \mathrm{~B}-\mathrm{DNJ}$. $N \mathrm{~N}$-DNJ has an antiviral effect on other members of the Flaviridae family of viruses, Japanese encephalitis virus (JEV) and dengue virus serotype $2 .{ }^{[46]}$

A study using a panel of galacto-imino sugars demonstrated a second antiviral property of long-chain compounds (optimally $N$-nonyl) against BVDV that is unrelated to the protein misfolding induced by gluco-analogues. Treatment of BVDVinfected cells with $N$-nonyl- and $N$-7oxadecyl-deoxygalactonojirimycin (9), that are not ER $\alpha$-glucosidase inhibitors, resulted in the secretion of viral particles with reduced infectivity. ${ }^{[47,48]}$

The re-emergence of dengue virus as a major human pathogen has led to an increase in studying the potential of imino sugars as therapeutics, with $\alpha$-glucosidase II being shown to be a host cell requirement for dengue virus infection. [63] The host cell factors for viral biogenesis is a particularly attractive target since treatment with imino sugars does not result in any escape mutants observed with other therapies, especially those dependent on virally encoded proteins. [64]

The main mechanism of action appears to be the inhibition of the ER 
Table 1.

\section{Structure}<smiles>CCCCN1CC(O)C(O)C(O)C1CO</smiles><smiles>OCC1NCC(O)C(O)C1O</smiles>

3<smiles>OCC1CNCC(O)C1O</smiles>

4<smiles>OCC1NCC(O)C(O)C1O</smiles><smiles>OCCN1CC(O)C(O)C(O)C1CO</smiles>

7

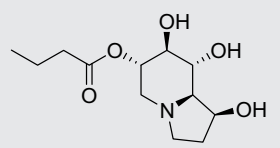

8

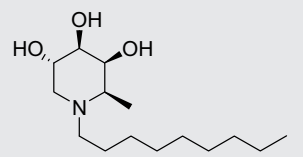

9

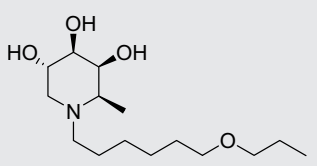

10<smiles>Nc1ccc(NCCCCCCN2CC(O)C(O)C(O)C2CO)c([N+](=O)[O-])c1</smiles>

11<smiles>C[C@H]1CCCCC1OCCCCCCCN1CC(O)C(O)[C@H](O)C1O</smiles><smiles>OCC1CN(CCCCOCC23CC4CC(CC(C4)C2)C3)CC(O)C1O</smiles>

\section{Gaucher \\ CFTR \\ Fabry}

Indication

Gaucher

Lysosomal glucocerebrosidase

Pompe

Lysosomal $\alpha$-glucosidase

Diabetes (Type II)

Sucrose isomaltase

Gaucher

Diabetes (Type II)

Sucrose isomaltase / Ceramide glucosyltransferase

ER $\alpha$-glucosidases I and II

HBV

Dengue

HCV

HBV

$\mathrm{HCV}$

p7

\section{Virally encoded ion channel}

Antiviral

Dengue Virus,

West Nile Virus,

BVDV

CFTR

Lysosomal $\alpha$-galactosidase

Ceramide glucosyltransferase (also p7

Virally encoded ion channel)

ER $\alpha$-glucosidases I and II

ER $\alpha$-glucosidases I and II

Unknown mechanism
Protein folding - ER $\alpha$-glucosidase

ER $\alpha$-glucosidases I and II

Drexel Institute for

Biotechnology and Virology

Research

Doylestown

Non- $\alpha$ - glucosidase based mechanism

AT1001 (Amigel, DGJ)

Phase III

Amicus

Phase II

(tartrate salt)

Amicus

AT2220 (DNJ)

Phase 1

Bayer

Glyset, Miglitol,

$\mathrm{N}$-hydroxyethyl-DNJ

Approved

(MX-3253)

Celgosivir

Phase II

Oxford University

(Lee et al., unpublished)
Ref

14

35

30

39-42

43-48

49

50

12 
$\alpha$-glucosidases since several broad spectrum antivirals act to a similar extent against viruses which have no viral ion pore, such as dengue virus, and no synergy with long alkyl chain imino sugars in viral ion pore dependent viruses, such as $\mathrm{HCV}$, is observed. The lack of ER access and poor inhibitory activity of clinically approved therapeutics such as NB-DNJ remains the major hurdle to an effective broad spectrum antiviral. This has led to two major developments for solving this problem; generating a better inhibitor of ER $\alpha$-glucosidases or providing a delivery method to the intracellular site of action. The latter has been achieved by targeted liposome-mediated delivery of imino sugars. This has been shown to be effective using weak cellular inhibitors, such as NB-DNJ, in HIV and HCV where in the latter virus, liposomes alone showed a dramatic effect in reducing viral copy numbers. ${ }^{665,66]}$ Other delivery improvements could utilise peptide-conjugated technology. However, in all cases the idea of an orally delivered monotherapy remains an attractive goal. A nanomolar $\alpha$-glucosidase inhibitor, NAP-DNJ (10) ${ }^{[49]}$ has been reported and although its full antiviral potential has yet to be fully characterised, should have considerable potential (Table 1). Other novel imino sugar derivatives (11) (Table 1) have also been shown to have potent antiviral activity against dengue in vitro and West Nile Virus as well as being significantly less cytotoxic than $N \mathrm{~N}-\mathrm{DNJ}$ for example. [50]

\section{Cystic Fibrosis}

Human genetic diseases such as cystic fibrosis (CF) and $\alpha 1$-antitrypsin deficiency are well known examples of impaired or aberrant folding in the ER where mutant polypeptides accumulate and are degraded by the cell before functionality is acquired. The most common mutation that results in $\mathrm{CF}$ is in the $\mathrm{CF}$ transmembrane regulator (CFTR), which is a chloride channel at the plasma membrane. ${ }^{[67]}$ The mutation is a deletion of Phe-508 ( $\triangle F 508)$ of CFTR leading to ER retention. ${ }^{[68]}$ However, this mutant would be functional if it were able to traffic correctly to the plasma membrane. ${ }^{[69]}$ Becq and colleagues showed that treatment with $N \mathrm{~B}$-DNJ appeared to prevent $\Delta \mathrm{F} 508-\mathrm{CFTR} /$ calnexin interaction and hence restored cAMP-activated chloride current in human and mouse epithelial CF cells. By contrast, NB-DGJ, had no effect. ${ }^{[35]}$ Moreover, NB-DNJ rescued a mature and functional $\triangle F 508-C F T R$ in the intestinal crypts of ileal mucosa from $\Delta$ F508 mice. ${ }^{[35]}$ Inhibition of glucosidases, the proposed mechanism of action, may not be an exclusive means whereby imino sugars can chaperone mutant proteins from the ER. The recently synthesised imino sugar IsoLAB (12) (Table 1), which has no ER $\alpha$-glucosidase or other glycohydrolase inhibitory activity, partially rescues defective $\Delta$ F508-CFTR. ${ }^{51]}$

\section{Conclusions and Future Perspectives}

Imino sugars may be powerful lead compounds to therapeutics. They can act as charge transition state analogues and enzyme inhibitors. The inhibitory potential of imino sugars has been harnessed to enhance enzyme activity due to their role as molecular chaperones. For therapeutic exploitation there is a need for better inhibitors/chaperones. NAP-DNJ for example is 50-fold better than NB-DNJ in vitro and in cells and could be predicted to have an improved activity in reducing viral biogenesis. One critical determinant for increasing potency is the length of the $\mathrm{N}$-alkyl chain, where a six-carbon spacer appears optimal for $\alpha$-glucosidase inhibition. [70] The addition of alkyl chains and a variety of substituents to the ring nitrogen permits endless scope for variety and can lead the archetypal imino sugar therapeutics away from perturbing classical carbohydrate pathways. Endocyclic nitrogen substitutions may improve secondary mechanisms and aid cellular or intracellular targeting which makes these attractive drug leads for the therapy of viral diseases, in particular.

\section{Acknowledgements}

The authors thank Professor Raymond Dwek and the Glycobiology Institute for support.

Received: September 3, 2010

[1] T. D. Butters, R. A. Dwek, F. M. Platt, Chem. Rev. 2000, 100, 4683.

[2] T. D. Butters, Expert. Opin. Pharmacother, 2007, $8,427$.

[3] T. D. Butters, R. A. Dwek, F. M. Platt, Glycobiology 2005, 15, 43R

[4] R. A. Dwek, T. D. Butters, F. M. Platt, N Zitzmann, Nat. Rev. Drug. Discov. 2002, 1, 65.

[5] A. Vellodi, Br. J. Haematol. 2005, 128, 413.

[6] A. H. Futerman, G. van Meer, Nat. Rev. Mol. Cell Biol. 2004, 5, 554.

[7] P. J. Meikle, J. J. Hopwood, A. E. Clague, W. F. Carey, J. Am. Med. Assoc. 1999, 281, 249.

[8] S. U. Walkley, Semin. Cell Dev. Biol. 2004, 15, 433.

[9] M. Jeyakumar, T. D. Butters, R. A. Dwek, F. M Platt, Neuropathol. Appl. Neurobiol. 2002, 28, 343.

[10] T. D. Butters, M. R. Wormald, R. A. Dwek, F M. Platt, L. A. G. M. Van Den Broek, G. W. J. Fleet, T. M. Krulle, Tetrahedron:Asymm. 2000, 11,113 .

[11] F. M. Platt, G. R. Neises, R. A. Dwek, T. D. Butters, J. Biol. Chem. 1994, $269,8362$.

[12] F. M. Platt, G. R. Neises, G. B. Karlsson, R. A Dwek, T. D. Butters, J. Biol. Chem. 1994, 269 , 27108.
[13] H. R. Mellor, J. Nolan, L. Pickering, M. R. Wormald, F. M. Platt, R. A. Dwek, G. W. J. Fleet, T. D. Butters, Biochem. J. 2002, 366, 225.

[14] T. Cox, R. Lachmann, C. Hollak, J. Aerts, S. van Weely, M. Hrebicek, F. Platt, T. Butters, R. Dwek, C. Moyses, I. Gow, D. Elstein, A. Zimran, Lancet 2000, 355, 1481.

[15] B. Bembi, F. Marchetti, V. I. Guerci, G. Ciana, R. Addobbati, D. Grasso, R. Barone, R. Cariati, L. Fernandez-Guillen, T. Butters, M. G. Pittis, Neurology 2006, 66, 278.

[16] G. H. Maegawa, B. L. Banwell, S. Blaser, G. Sorge, M. Toplak, C. Ackerley, C. Hawkins, J. Hayes, J. T. Clarke, Mol. Genet. Metab. 2009, 98, 215.

[17] G. H. Maegawa, P. L. van Giersbergen, S. Yang, B. Banwell, C. P. Morgan, J. Dingemanse, C. J. Tifft, J. T. Clarke, Mol. Genet. Metab. 2009, 97 , 284.

[18] M. C. Patterson, D. Vecchio, E. Jacklin, L. Abel, H. Chadha-Boreham, C. Luzy, R. Giorgino, J. E. Wraith, J. Child. Neurol. 2010, 25, 300.

[19] M. C. Patterson, D. Vecchio, H. Prady, L. Abel, J. E. Wraith, Lancet Neurol. 2007, 6, 765 .

[20] M. Pineda, J. E. Wraith, E. Mengel, F. Sedel, W. L. Hwu, M. Rohrbach, B. Bembi, M. Walterfang, G. C. Korenke, T. Marquardt, C. Luzy, R. Giorgino, M. C. Patterson, Mol. Genet. Metab. 2009, 98, 243.

[21] R. Schiffmann, E. J. Fitzgibbon, C. Harris, C. DeVile, E. H. Davies, L. Abel, I. N. van Schaik, W. Benko, M. Timmons, M. Ries, A. Vellodi, Ann. Neurol. 2008, 64, 514.

[22] B. E. Shapiro, G. M. Pastores, J. Gianutsos, C. Luzy, E. H. Kolodny, Genet. Med. 2009, 11, 425.

[23] C. M. Tallaksen, J. E. Berg, J. Inherit. Metab. Dis., Case Report \#004, 2009.

[24] S. B. Wortmann, D. J. Lefeber, G. Dekomien, M. A. Willemsen, R. A. Wevers, E. Morava, $J$. Inherit. Metab. Dis., Short Report \#188, 2009.

[25] M. Zarowski, B. Steinborn, B. Gurda, L. Dvorakova, H. Vlaskova, S. V. Kothare, Eur. J. Paediatr. Neurol. 2010, in press.

[26] T. Wennekes, R. J. van den Berg, W. Donker, G. A. van der Marel, A. Strijland, J. M. Aerts, H. S. Overkleeft, J. Org. Chem. 2007, 72, 1088.

[27] a) R. Lysek, C. Schütz, P. Vogel, Bioorg. Med. Chem. Lett. 2005, 15, 3071; b) R. Lysek, P. Vogel, Tetrahedron 2006, 62, 2733; c) R. Lysek, S. Favre, P. Vogel, Tetrahedron 2006, 63, 6558.

[28] a) V. Faugeroux, Y. Genisson, N. AndrieuAbadie, S. Colie, T. Levade, M. Baltas, Org. Biomol. Chem. 2006, 4, 4437; b) C. Boucheron, V. Desvergnes, P. Compain, O. R. Martin, A. Lavi, M. Mackeen, M. R. Wormald, R. A. Dwek, T. D. Butters, Tetrahedron:Asymm. 2005, 16, 1747.

[29] J. Q. Fan, Trends Pharmacol. Sci. 2003, 24, 355.

[30] N. Asano, S. Ishii, H. Kizu, K. Ikeda, K Yasuda, A. Kato, O. R. Martin, J. Q. Fan, Eur. J. Biochem. 2000, 267, 4179.

[31] R. A. Steet, S. Chung, B. Wustman, A. Powe, H. Do, S. A. Kornfeld, Proc. Natl. Acad. Sci. USA 2006, 103, 13813.

[32] R. Khanna, E. R. Benjamin, L. Pellegrino, A. Schilling, B. A. Rigat, R. Soska, H. Nafar, B. E. Ranes, J. Feng, Y. Lun, A. C. Powe, D. J. Palling, B. A. Wustman, R. Schiffmann, D. J. Mahuran, D. J. Lockhart, K. J. Valenzano, FEBS J. 2010, 277, 1618.

[33] R. Khanna, R. Soska, Y. Lun, J. Feng, M. Frascella, B. Young, N. Brignol, L. Pellegrino, S. A. Sitaraman, R. J. Desnick, E. R. Benjamin, D. J. Lockhart, K. J. Valenzano, Mol. Ther. 2010, 18, 23.

[34] P. Alfonso, S. Pampin, J. Estrada, J. C. Rodriguez-Rey, P. Giraldo, J. Sancho, M. Pocovi, Blood Cells Mol. Dis. 2005, 35, 268.

[35] C. Norez, S. Noel, M. Wilke, M. Bijvelds, H. 
Jorna, P. Melin, H. DeJonge, F. Becq, FEBS Lett. 2006, 580, 2081.

[36] C. Porto, M. Cardone, F. Fontana, B. Rossi, M. R. Tuzzi, A. Tarallo, M. V. Barone, G. Andria, G. Parenti, Mol. Ther. 2009, 17, 964 .

[37] J. M. Aerts, R. Ottenhoff, A. S. Powlson, A. Grefhorst, M. van Eijk, P. F. Dubbelhuis, J. Aten, F. Kuipers, M. J. Serlie, T. Wennekes, J. K. Sethi, S. O'Rahilly, H. S. Overkleeft, Diabetes 2007, 56, 1341

[38] T. Wennekes, A. J. Meijer, A. K. Groen, R. G. Boot, J. E. Groener, M. van Eijk, R. Ottenhoff, N. Bijl, K. Ghauharali, H. Song, T. J. O'Shea, H. Liu, N. Yew, D. Copeland, R. J. van den Berg, G. A. van der Marel, H. S. Overkleeft, J. M. Aerts, J. Med. Chem. 2010, 53, 689.

[39] D. L. Taylor, P. S. Sunkara, P. S. Liu, M. S. Kang, T. L. Bowlin, A. S. Tyms, AIDS 1991, 5 , 693

[40] C. G. Bridges, S. P. Ahmed, M. S. Kang, R. J. Nash, E. A. Porter, A. S. Tyms, Glycobiology 1995, 5, 249.

[41] P. A. Norton, S. Menne, G. Sinnathamby, L. Betesh, P. J. Cote, R. Philip, A. S. Mehta, B. C. Tennant, T. M. Block, Hepatology, 2010, in press.

[42] W. Schul, W. Liu, H. Ä. Xu, M. Flamand, S. G. Vasudevan, J. Infect. Dis. 2007, 195, 665

[43] T. M. Block, X. Lu, A. S. Mehta, B. S. Blumberg, B. Tennant, M. Ebling, B. Korba, D. M. Lansky, G. S. Jacob, R. A. Dwek, Nat. Med. 1998, 4, 610 .

[44] N. Branza-Nichita, D. Durantel, S. CarroueeDurantel, R. A. Dwek, N. Zitzmann, J. Virol 2001, 75, 3527 .

[45] N. Zitzmann, A. S. Mehta, S. Carrouee, T. D. Butters, F. M. Platt, J. McCauley, B. S. Blumberg, R. A. Dwek, T. M. Block, Proc. Natl. Acad. Sci. USA 1999, 96, 11878.

[46] S. F. Wu, C. J. Lee, C. L. Liao, R. A. Dwek, N. Zitzmann, Y. L. Lin, J. Virol. 2002, 76, 3596.

[47] D. Durantel, N. Branza-Nichita, S. CarroueeDurantel, T. D. Butters, R. A. Dwek, N. Zitzmann, J. Virol. 2001, 75, 8987.
[48] D. Pavlovic, D. C. Neville, O. Argaud, B. Blumberg, R. A. Dwek, W. B. Fischer, N Zitzmann, Proc. Natl. Acad. Sci. USA 2003, 100, 6104.

[49] A. J. Rawlings, H. Lomas, A. W. Pilling, M. J. Lee, D. S. Alonzi, J. S. S. Rountree, S. F. Jenkinson, G. W. J. Fleet, R. A. Dwek, J. H. Jones, T. D. Butters, ChemBioChem. 2009, 10, 1101.

[50] J. Chang, L. Wang, D. Ma, X. Qu, H. Guo, X. $\mathrm{Xu}, \mathrm{P}$. M. Mason, N. Bourne, R. Moriarty, B. Gu, J. T. Guo, T. M. Block, Antimicrob. Agents Chemother. 2009, 53, 1501.

[51] D. Best, S. F. Jenkinson, A. W. Saville, D. S. Alonzi, M. R. Wormald, T. D. Butters, C. Norez, F. Becq, Y. Bleriot, I. Adachi, A. Kato, G. W. J. Fleet, Tetrahedron Lett. 2010, 51, 4170.

[52] T. Wennekes, R. J. van den Berg, R. G. Boot, G. A. van der Marel, H. S. Overkleeft, J. M. Aerts, Angew. Chem. Int. Ed. 2009, 48, 8848.

[53] R. A. Gruters, J. J. Neefjes, M. Tersmette, R. E. de Goede, A. Tulp, H. G. Huisman, F. Miedema, H. L. Ploegh, Nature 1987, 330, 74.

[54] a) B. D. Walker, M. Kowalski, W. C. Goh, K. Kozarsky, M. Krieger, C. Rosen, L. Rohrschneider, W. A. Haseltine, J. Sodroski, Proc. Natl. Acad. Sci. USA 1987, 84, 8120; b) I. Robina, A. J. Moreno-Vargas, A. T. Carmona, P. Vogel, Curr. Drug Metabolism 2004, 5, 329.

[55] G. W. Fleet, A. Karpas, R. A. Dwek, L. E. Fellows, A. S. Tyms, S. Petursson, S. K. Namgoong, N. G. Ramsden, P. W. Smith, J. C. Son, et al., FEBS Lett. 1988, 237, 128.

[56] G. B. Karlsson, T. D. Butters, R. A. Dwek, F. M. Platt, J. Biol. Chem. 1993, 268, 570

[57] P. B. Fischer, G. B. Karlsson, T. D. Butters, R. A. Dwek, F. M. Platt, J. Virol. 1996, 70, 7143.

[58] P. B. Fischer, G. B. Karlsson, R. A. Dwek, F. M Platt, J. Virol. 1996, 70, 7153.

[59] M. Tierney, J. Pottage, H. Kessler, M. Fischl, D. Richman, T. Merigan, W. Powderly, S. Smith, A. Karim, J. Sherman, et al., J. Acquir. Immune Defic. Syndr. Hum. Retrovirol. 1995, 10, 549.

[60] M. A. Fischl, L. Resnick, R. Coombs, A. B Kremer, J. C. Pottage, Jr., R. J. Fass, K. H. Fife,
W. G. Powderly, A. C. Collier, R. L. Aspinall, et al., J. Acquir. Immune Defic. Syndr. 1994, 7 , 139.

[61] H. R. Mellor, D. C. Neville, D. J. Harvey, F. M. Platt, R. A. Dwek, T. D. Butters, Biochem. J. 2004, 381, 861.

[62] L. A. G. M. van den Broek, D. J. Vermaas, F. J. van Kemenade, M. C. C. A. Tan, F. T. M. Rotteveel, P. Zandberg, T. Butters, F. Miedema, H. L. Ploegh, C. A. A. van Boeckel, Recl. Trav. Chim. Pays-Bas 1994, 113, 507.

[63] O. M. Sessions, N. J. Barrows, J. A. Souza-Neto, T. J. Robinson, C. L. Hershey, M. A. Rodgers, J. L. Ramirez, G. Dimopoulos, P. L. Yang, J. L. Pearson, M. A. Garcia-Blanco, Nature 2009, $458,1047$.

[64] S. D. Woodhouse, C. Smith, M. Michelet, N Branza-Nichita, M. Hussey, R. A. Dwek, N. Zitzmann, Antimicrob. Agents Chemother. 2008, 52, 1820.

[65] S. Pollock, R. Antrobus, L. Newton, B. Kampa, J. Rossa, S. Latham, N. B. Nichita, R. A. Dwek, N. Zitzmann, FASEB J. 2010, 24, 1866.

[66] S. Pollock, R. A. Dwek, D. R. Burton, N Zitzmann, AIDS 2008, 22, 1961.

[67] M. J. Welsh, M. P. Anderson, Soc. Gen. Physiol. Ser. 1993, 48, 119.

[68] S. H. Cheng, R. J. Gregory, J. Marshall, S. Paul, D. W. Souza, G. A. White, C. R. O'Riordan, A. E. Smith, Cell 1990, 63, 827.

[69] G. M. Denning, M. P. Anderson, J. F. Amara, J. Marshall, A. E. Smith, M. J. Welsh, Nature 1992, 358, 761.

[70] D. S. Alonzi, R. A. Dwek, T. D. Butters, Tetrahedron:Asymm. 2009, 20, 897. 